\title{
Dinamika Sosial Sikap Narcisstic Aksi Demonstrasi Mahasiswa Dalam Prospek Demokrasi Indonesia
}

\author{
Ilham Syahrul Jiwandono ${ }^{1}$ \\ ${ }^{1}$ Dosen Pendidikan Guru Sekolah Dasar, Universitas Mataram, Indonesia \\ Email: ilham jiwandono@unram.ac.id
}

\begin{abstract}
This research aims to find out narcissistic phenomena in demonstrations carried out by students in the prospect of democracy in Indonesia as well as the causes. The research approach uses a qualitative approach. Research location in Elementary School Teacher Education Study Program, University of Mataram. Data sources are divided into two, namely primary and secondary. Primary data sources are 5th semester students taking part in demonstrations and secondary data sources namely observation and documentation. Data collection techniques through interviews, observation and documentation. Data analysis techniques through data reduction, data presentation and verification. The results showed: 1) The democratic climate in Indonesia developed well by involving students in controlling the legislative and executive branches. 2) There has been a shift in the nuances of the demonstration today compared to some time ago. Nowadays students tend to be narcissistic in demonstrations and forget the substance of demonstrations. 3) The contributing factor is the development of increasingly sophisticated technology and makes students want to display their existence through demonstrations and then uploaded on social media. 4) Students as the Z generation want every activity to be known by many people, including through demonstrations aimed at getting attention and praise.
\end{abstract}

Keywords : Narcisstic, Demonstration, Democracy

\begin{abstract}
Abstrak. Penelitian ini bertujuan untuk mengetahui fenomena narcisstic dalam aksi demonstrasi yang dilakukan oleh mahasiswa dalam prospek demokrasi di Indonesia serta faktor-faktor penyebabnya. Pendekatan penelitian menggunakan pendekatan kualitatif. Lokasi penelitian di Program Studi Pendidikan Guru Sekolah Dasar, Universitas Mataram. Sumber data dibagi menjadi dua, yakni primer dan sekunder. Sumber data primer yakni mahasiswa semester 5 yang ikut aksi demonstrasi dan sumber data sekunder yakni hasil observasi dan dokumentasi. Teknik pengumpulan data melalui wawancara, observasi dan dokumentasi. Teknik analisis data melalui reduksi data, penyajian data dan verifikasi. Hasil penelitian menunjukkan: 1) Iklim demokrasi di Indonesia berkembang dengan baik dengan turut sertanya mahasiswa dalam mengontrol legislatif dan eksekutif. 2) Terjadi pergeseran nuansi demonstrasi saat ini dibandingkan dengan beberapa waktu yang lalu. Saat ini mahasiswa cenderung narsis dalam aksi demonstrasi dan melupakan substansi demonstrasi. 3) Faktor yang menyebabkan adalah perkembangan teknologi yang semakin canggih dan membuat mahasiswa ingin menampilkan eksistensi dirinya melalui aksi demonstrasi lalu diunggah di media sosial. 4) Mahasiswa sebagai generasi Z menginginkan setiap aktivitasnya diketahui oleh banyak orang, termasuk melalui aksi demonstrasi yang bertujuan untuk mendapatkan perhatian dan pujian.
\end{abstract}

Kata kunci : Narcisstic, Demonstrasi, Demokrasi

\section{PENDAHULUAN}

Aksi demonstrasi meletus di berbagai daerah di Indonesia beberapa waktu yang lalu. Demonstrasi yang mereka lakukan di banyak tempat memiliki latar belakang yang sama, yakni menolak RUU KPK dan RUU KUHP. Mereka menganggap kedua peraturan tersebut dan peraturan beleid lainnya mencederai demokrasi. Mayoritas aksi demontrasi tersebut berakhir dengan kericuhan yang menyebabkan banyak 
kerugian harta, benda bahkan nyawa. Namun, yang menjadi sorotan dalam demonstrasi tersebut bukanlah aksi kericuhannya, namun sikap para demonstrannya. Terjadi persegeseran aksi demonstrasi mahasiswa dalam beberapa tahun terakhir. Jika biasanya aksi demonstrasi mahasiswa identik dengan kekritisan, namun saat ini bergeser ke narcisstic.

Demonstrasi tidak hanya dimaknai sebagai aksi menyampaikan aspirasi saja, namun juga menjadi ajang untuk menampilkan aktualisasi dirinya melalui demonstrasi yang kemudian diunggah melalui media sosial. Sikap ini terekam dalam berbagai aksi demonstrasi beberapa waktu lalu di berbagai daerah di Indonesia, mulai dari Jakarta, Yogyakarta, Solo, Surabaya, Malang, Makassar hingga Kota Mataram. Dengan bangganya mereka menuliskan kata-kata mutiara yang sebenarya tidak ada kaitannya dengan apa yang mereka suarakan dalam aksi demonstrasi. Tujuan mereka tak lain dan tak bukan adalah untuk menunjukkan keterlibatan mereka di peristiwa-peristiwa penting demi mendapatkan pujian dan pengakuan dari orang lain. Dari wawancara awal yang dilakukan kepada narasumber diperoleh informasi bahwa mereka melakukan hal tersebut demi mendapatkan like dan komentar di sosial media mereka. Sikap mahasiswa ini tentunya akan mempengaruhi iklim dan prospek demokrasi Indonesia ke depan. Demokrasi yang ada di indoensia tidak hanya menuntut perubahan lembaga-lembaga politik, melainkan juga para pelaku demokrasi itu sendiri.

Aksi demonstrasi yang mahasiswa lakukan adalah bentuk kontrol mereka terhadap jalannya roda pemerintahan dan harusnya tidak ada ketakutan dari lembaga eksekutif maupun legislatif. Ada keunikan yang menarik untuk diteliti bahwa saat ini bentuk kontrol oleh mahasiswa tidak hanya melalui orasi di atas panggung atau di atas mobil. Namun, banyak mahasiswa peserta aksi demonstrasi menggunakan poster-poster untuk memberikan kritikan kepada wakil mereka di parlemen. Hal ini jelas merupakan hal baru yang jarang ditemui dalam beberapa tahun yang lalu. Apa yang dilakukan mahasiswa ini patut mendapat apresiasi bahwa ada hal baru yang dapat digunakan untuk menyalurkan aspirasinya. Kenyataan ini tentunya akan sangat mempengaruhi prospek demokrasi Indonesia ke depannya dan menjadi bukti bahwa demokrasi di Indonesia saat ini sedang sehat. Perkembangan demokrasi tidak hanya dipengaruhi oleh elite-elite politik yang ada di tingkat pusat, namun juga dipengaruhi oleh para mahasiswa yang tersebar di kampus-kampus.

\section{METODE PENELITIAN}

Penelitian ini menggunakan metode penelitian kualitatif dengan jenis deskriptif. Dalam penelitian kualitatif, data yang dihasilkan berupa kata-kata tertulis maupun lisan yang dijelaskan secara deskriptif sebagai hasil dari pengamatan di lapangan. Mengutip pendapat Moleong (2018), penelitian kualitatif adalah penelitian yang bertujuan untuk memahami fenomena-fenomena yang ada di masyarakat. Teknik pengambilan data pada penelitian ini menggunakan wawancara, dokumentasi dan observasi. Teknik analisis data menggunakan teknik Miles dan Huberman bahwa ada tiga alur teknik analisis data, yakni reduksi data, penyajian data dan penarikan kesimpulan. Lokasi penelitian di Program Studi Pendidikan Guru Sekolah Dasar Universitas Mataram. Sumber data dalam penelitian ini dibagi menjadi dua, yakni sumber data primer dan sumber data sekunder. Sumber data primer yakni mahasiswa yang ikut aksi demonstrasi sedangkan sumber data sekunder berupa observasi dan dokumentasi aksi demonstrasi dan berbagai berita yang ada di media massa.

\section{HASIL DAN PEMBAHASAN}

\section{A. Perkembangan Demokrasi di Indonesia}

Indonesia adalah negara besar dengan berbagai keunikannya, termasuk di bidang pemerintahan. Indonesia boleh dikatakan sebagai kiblat negara demokrasi di kawasan Asia (Nihaya, 2011). Hal ini berkat keberhasilan Indonesia dalam mengembangkan dan melaksanakan sistem demokrasi, termasuk kesuksesan Indonesia dalam melaksanakan pemilu legislatif dan pemilu presiden 2019.

Bahkan, Indonesia masuk dalam kajian Global Democracy Ranking (Fithriana, 2016). Hal ini telah membuka mata dunia luar bahwa Indonesia mempunyai potensi yang besar untuk memimpin datangnya negara demokratis. Setidaknya Indonesia telah melalui empat fase demokrasi, yakni demokrasi liberal, demokrasi terpimpin, demokrasi Pancasila dan demokrasi yang berkembang saat ini. Keempat fase demokrasi ini membuat Indonesia semakin mengokohkan dirinya sebagai negara demokrasi. Namun yang 
perlu digarisbawahi dalam praktik demokrasi di Indonesia adalah semakin sedikitnya peran rakyat dalam penentuan kebijakan negara maupun dalam perumusan peraturan perundang-undangan. Hal ini sesuai dengan pendapat Irawan (2007) yang mengatakan bahwa dalam pelaksanaan demokrasi saat ini yang menempatkan rakyat dalam penentuan kebijakan negara, seringkali bergeser saat pemerintahan melakukan pembatasan terhadap kehendak rakyat dalam praktik bernegara.

Pernyataan tersebut dibuktikan dengan kasus yang terjadi beberapa waktu lalu tentang rancangan undang undang KPK yang dianggap tidak melibatlan rakyat dalam perumusannya. Hal ini memantik amarah mahasiswa yang mengatasnamakan rakyat untuk membatalkan rancangan undang-undang tersebut. Hal diatas diperkuat oleh hasil wawancara dengan mahasiswa peserta aksi demonstrasi yang mengatakan bahwa mereka melakukan demonstrasi karena tidak puas dengan kinerja pemerintah dan parlemen karena tidak melibatkan dan mendengarkan rakyat dalam perumusan peraturan perundangundangan. Dalam perjalanannya, demokrasi di Indonesia tidak selamanya dilaksanakan sejalan dengan konstitusi. Hal ini dibuktikan dengan masih besarnya peran pemerintah dalam mewarnai sistem demokrasi di Indonesia. Padahal, sesuai dengan amanat UUD NRI 1945, rakyat adalah pemegang kekuasaan tertinggi yang saat ini malah rakyat dipaksa untuk patuh terhadap elite-elite politik yang menjalankan sistem demokrasi. Apa yang dilakukan mahasiswa beberapa waktu lalu patut mendapatkan apresiasi karena mempunyai keinginan kuat untuk mengembalikan kedaulatan rakyat. Hasil wawancara dengan narasumber diperoleh informasi bahwa saat ini rakyat merasa muak dengan beberapa anggota parlemen yang tidak mau mendengarkan aspirasi rakyat, padahal mereka adalah wakil rakyat yang semestinya mendengarkan aspirasi yang memilihnya sehingga dia duduk di senayan.

Demokrasi yang ideal adalah demokrasi yang memberikan kesempatan kepada rakyat untuk menentukan kehidupannya dengan melibatkan mereka dalam berbagai kebijakan yang dikeluarkan oleh pemerintah. Walaupun Indonesia dikatakan sebagai demokrasi yang besar, namun pada praktiknya masih menemui banyak permasalahan yang membutuhkan penanganan yang serius, rakyat sebagai pemegang kekuasaan tertinggi dalam sistem demokrasi seharusnya mendapat peran yang besar dalam menentukan arah negara. Namun kenyataannya rakyat masih terbelenggu oleh berbagai kepentingan yang dilakukan oleh berbagai pihak yang mengatasnamakan rakyat.

\section{B. Kecenderungan Sikap Narsisme Mahasiswa}

Tidak dapat dipungkiri bahwa mahasiswa saat ini mempunyai kecenderungan untuk narsis. Sorokowska, dkk (2016) menjelaskan bahwa intensitas mengunggah foto di media sosial berhubungan dengan exshibitionism yang merupakan salah satu aspek dari narsisme. Exhibitionism adalah seseorang yang senang ketika memamerkan segala kelebihannya dengan orang lain seperti penampilan fisik, status sosial, dan harta benda yang dimilikinya. Penampilan fisik, status sosial dan harta seseorang dapat dengan mudah memamerkannya dengan mengunggah fotonya di media sosial. Mahasiswa yang memiliki sifat narsis tidak hanya yang gemar memotret diri sendiri lalu mengunggahnya di media sosial, akan tetapi juga gemar membanggakan diri sendiri pada orang lain. Hal ini sesuai dengan pendapat narasumber yang mengatakan bahwa tujuan mereka mengunggah foto ke media sosial adalah untuk menunjukkan eksistensinya kepada orang lain. Pernyataan ini wajar karena manusia memang mempunyai sifat seperti itu. Mahasiswa yang mempunyai kecenderungan narsis biasanya tidak percaya diri dengan apa yang dimiliki serta tidak mampu menyesuaikan diri sehingga mereka membutuhkan pengakuan dari orang lain. Hal tersebut sesuai dengan pendapat Beck, dkk., (Halgin \& Whitbourne, 2010) yang menjelaskan bahwa orang-orang dengan narsisme berpegang pada gagasan ketidakmampuan menyesuaikan diri sendiri, termasuk pandangan bahwa mereka adalah orang yang luar biasa yang pantas diperlakukan lebih baik dari pada manusia biasa.

Sikap narsisme yang dimiliki oleh mahasiswa memliki tingkatan. Menurut Raskin dan Terry (1988) terdapat tujuh karakteristik pada narsisme, yaitu : 1) Authority, yaitu anggapan seseorang yang memiliki otoritas sebagai pemimpin untuk memengaruhi orang lain. 2) Self-sufficiency, yaitu kebutuhan ingin dicintai untuk memenuhi kebutuhan psikologis seseorang kepada orang lain. 3) Superiority, yaitu perasaan superior seseorang yang menilai dirinya lebih dari orang lain. 4) Exhibitionism, suka membesarbesarkan atau memamerkan kelebihan seseorang kepada orang lain. 5) Exploitativeness, yaitu mengekspolitasi seseorang sesuai dengan kehendaknya sendiri. 6) Vanity, yaitu rasa megah diri seseorang dan merasa angkuh atau sombong kepada orang lain. 7) Entitlement, yaitu seseorang merasa bahwa dirinya berhak mendapatkan kekuasaan untuk mendapatkan keistimewaan dari orang lain. Dari hasil 
wawancara dengan narasumber diperoleh informasi bahwa mayoritas narsumber berada pada tingkatan Exhibitionism dimana mereka suka memamerkan kehidupannya kepada orang lain.

Salah satu sifat manusia adalah menceritakan keberhasilannya kepada orang lain. Hal ini bertujuan untuk menunjukkan bahwa dia adalah seseorang yang bisa melakukan banyak hal. Pendapat Otniel (2007) menguatkan pernyataan tersebut. Dia merasa bahwa orang lain perlu mengetahu kesuksesan yang dimilikinya dan sering menceritakan keberhasilan dirinya kepada orang lain. Disisi lain, seseorang yang gemar narsis memiliki kecenderungan untuk kepentingan diri sendiri dan sedikit memiliki rasa empati kepada orang lain. Hal ini terjadi karena secara tidak langsung seseorang tersebut membandingkan dirinya dengan orang lain. Selain itu, banyak seseorang yang narsis guna mendapatkan keuntungan diri sendiri dengan memanfaatkan orang lain. Pernyataan ini sejalan dengan pendapat Duran dan Barlow (2007: 212) yang menjelaskan bahwa individu dengan kecenderungan narsisme memanfaatkan orang lain untuk kepentingan diri sendiri dengan menunjukkan hanya sedikit empati kepada orang lain. Hasil wawancara dengan responden juga menunjukkan hal tersebut. Responden menjelaskan bahwa dia memposting fotonya dalam aksi demonstrasi untuk menunjukkan bahwa dia mempunyai keberanian untuk mengemukakan pendapatnya dibandingkan dengan mahasiswa lain yang tidak ikut demonstrasi.

\section{Sikap Narsisme Mahasiswa dalam Aksi Demonstrasi}

Demonstrasi merupakan salah satu ciri khas bahwa negara tersebut memakai sistem demokrasi, hal ini tidak akan ditemukan di negara yang mengantut sistem otoriter. Aksi demontrasi adalah suatu model pernyataan sikap, penyuaraan pendapat, opini, atau tuntutan yang dilakukan dengan jumlah massa tertentu dan dengan teknik tertentu agar mendapat perhatian dari pihak yang dituju tanpa menggunakan mekanisme konvensional (birokrasi). Demonstrasi juga bertujuan untuk menekan pembuat kebijakan untuk melakukan atau tidak melakukan sesuatu. Aksi demonstrasi yang dilakukan oleh mahasiswa beberapa waktu yang lalu merupakan bentuk protes sekaligus kontrol terhadap wakil mereka di pemerintahan.

Fakta tersebut menunjukkan bahwa saat ini menunjukkan bahwa respon mahasiswa terhadap berbagai permasalahan di negara ini sangat tinggi. Namun yang disayangkan adalah demonstrasi yang mahasiswa lakukan pada umumnya berakhir dengan bentrokan. Harus dipahami bahwa demonstrasi adalah bagian dari adanya perubahan dalam masyarakat, tetapi aksi demosntrasi mempunyai ruang yang luas untuk terjadinya tindakan yang melanggar hukum dan menggangggu kepentingan umum. Terdapat tiga fakor yang mempengaruhi aksi demonstrasi berujung dengan bentrokan, pertama adanya rasa ketidakadilan, kedua adanya ancaman subsistensi dan yang ketiga adalah adanya pelanggaran terhadap hak asasi manusia. Hasil observasi di lapangan dapat diketahui bahwa pola serta kecenderungan kekerasan hamper dipastikan sama. Hal ini sesuai dengan pendapat Hasse (2017) yang mengatakan bahwa kalau diamati tentang karakter mahasiswa ketika demonstrasi, maka dapat diprediksi mana demonstrasi yang akan berujung pada kericuhan dan mana yang tidak berakhir dengan kericuhan.

Demonstrasi yang berujung kericuhan dan bentrokan merupakan hal biasa yang hampir kita temui dalam berbagai kesempatan. Yang tidak biasa adalah demonstrasi yang dijadikan ajang untuk menampilkan eksistensi peserta demo. Realita ini yang sekarang sedang berkembang di negara kita. Dalam keseharian di lingkungan masyarakat, tentunya tidak asing lagi dengan narsisme. Engkus (2017) mengatakan bahwa narsisme merupakan salah satu penyimpangan kepribadian yang terjadi akibat seseorang tersebut memeiliki perasaan yang sangat berlebihan bahwa dirinya adalah seseorang yang penting dan layak untuk dipuji. Seseorang yang merasa narsis akan merasa bahwa dirinya adalah yang paling penting dan kurang menghargai perasaan orang lain.

Aksi demonstrasi menjadi sarana yang paling sering digunakan pada masa sekarang ini. Namun dengan maraknya aksi demonstrasi yang hampir setiap hari dapat kita jumpai membuat masyarakat seakan mulai jenuh karena tidak melihat hasil riil dari aksi tersebut. Hingga terkadang bermunculan stigma negatif dari masyarakat yang menilai aksi demonstrasi percuma dilakukan, bahkan dinilai aksi demonstrasi hanya untuk kepentingan politik praktis hingga aksi demonstrasi bayaran pun kerap dilontarkan masyarakat.

Terjadi perubahan nuansa demonstrasi, dari yang awalnya identik dengan penyampaian aspirasi melalui microfon, saat ini bergeser dengan menggunakan poster-poster. Yang menjadi masalah adalah poster-poster yang dibawa ini tidak berkaitan dengan substansi demonstrasi. Berikut gambarnya: 


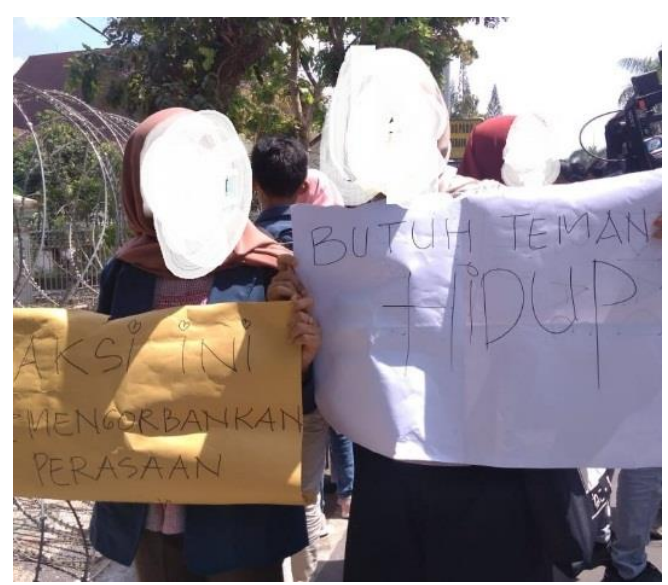

Gambar 1: Poster yang dibawa mahasiswa

Gambar diatas menunjukkan bahwa peserta aksi tidak memahami apa yang mereka demonstrasikankan. Hal tersebut dibuktikan dengan poster yang bertuliskan "ketika cucu kakek sugiono turun, itu artinya Indonesia sedang mendesah". Tulisan yang mereka buat tidak mencerminkan substansi demontrasi yang menuntut pembatalan RUU KPK dan RUU KUHP. Poster yang mereka bawa jauh dari tema demonstrasi yang sedang berlangsung. Hal ini menjadi keunikan tersendiri mengingat demonstrasi saat ini dijadikan ajang untuk mengaktualisasikan diri. Hasil wawancara dengan narasumber diperoleh informasi bahwa demonstrasi merupakan peristiwa penting yang banyak mendapat sorotan media sehingga menjadi tempat favorit untuk menampilkan eksistensi dirinya.

Narasumber melanjutkan bahwa poster-poster yang mereka bawa kemudian mereka foto di lokasi demonstrasi dan kemudian akan di upload di media sosial, salah satunya adalah Instagram. Hal ini penting dipahami bahwa kebutuhan akan aktulisasi diri saat ini menjadi sangat penting apalagi dengan berkembangnya teknologi (Izzati, 2018). Aktualisasi diri ini dapat disalurkan melalui berbagai cara, salah satunya numpang dalam peristiwa penting seperti halnya demontrasi. Berikut gambarnya:

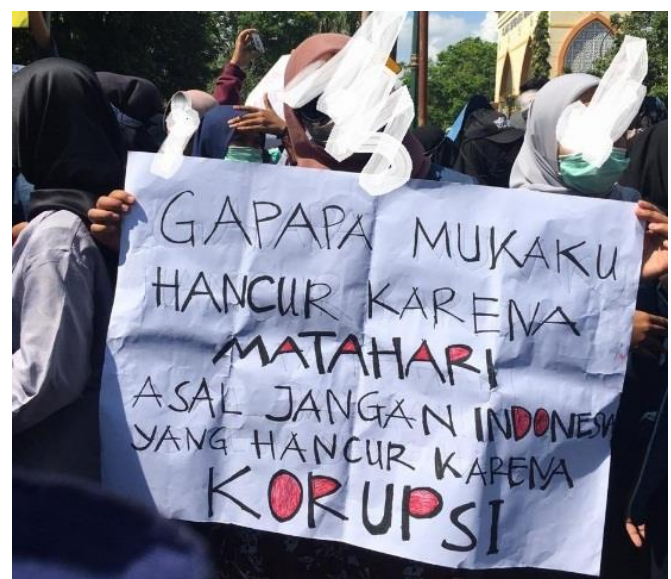

Gambar 2: Tulisan yang mahasiswa buat dalam aksi demonstrasi

Generazi $Z$ memang punya acara tersendiri dalam menampilkan eksistensinya dibandingkan dengan generasi $Y$. Generasi $Z$ bisa memanfaatkan berbagai situasi dalam menampilkan eksistensinya, termasuk dalam aksi demonstrasi sekalipun. Namun, apa yang ditampilkan oleh mahasiswa terlalu berlebihan sehingga mengganggu kenyamanan orang lain. Nah, kecintaan terhadap diri sendiri yang terlalu berlebihan sehingga mengganggu kenyaanan tentunya dapat dikatakan sebagai gangguan kepibadian (Hardjanta, dalam Philip, 2007). Hal ini sesuai dengan hasil dokumentasi yang dilakukan bahwa terdapat beberapa mahasiswa yang mengganggu kenyamanan orang lain sebagai akibat dari eksistensi mereka di aksi demonstrasi. Narsisme memiliki tingkatan. Seseorang yang melakukan sedikit narsisme masih dianggap normal. Sedangkan seseorang yang perilaku narsismenya sudah berat maka bisa 
menjadi indikasi adanya gangguan kepribadian. Apa yang mereka lakukan tentunya bisa termasuk gangguan kepribadian. Berikut contoh gambarnya :

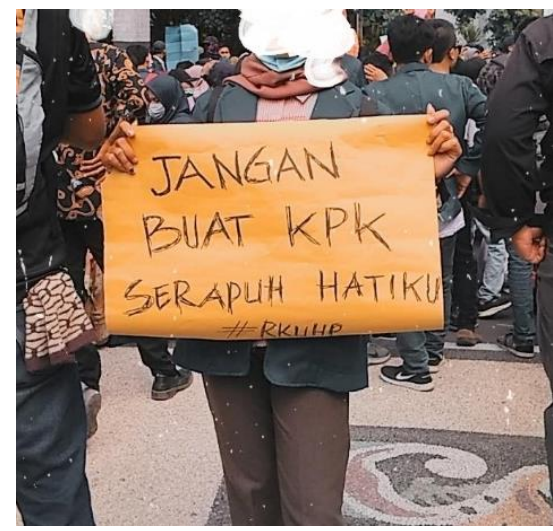

Dari gambar diatas dapa disimpulkan bahwa mahasiswa kurang mengerti dengan apa yang mereka suarakan. Mereka semata-mata hanya ingin membanggakan dirinya demi mendapat pujian dari orang lain. Hasil wawancara dengan narasumber diperoleh informasi bahwa memang mereka suka membanggakan dirinya sendiri sehingga dia pergi ke aksi demonstrasi semata-mata hanya ingin menunjukkan bahwa dia terlibat dalam peristiwa penting. Hal ini sesuai dengan pendapat narasumber yang berprofesi sebagai dosen yang mengatakan bahwa ciri-ciri seseorang yang narcisstic adalah mereka yang senang membanggakan dirinya sendiri dengan tujuan agar mendapatkan pujian dari orang lain. Hasil wawancara dengan narasumebr lain diproleh informasi bahwa mahasiswa yang ikut demonstrasi umumnya dibagi menjadi dua, yakni hanya sekadar ikut dan mahasiswa yang aktif berorganisasi. Hal ini diperkuat oleh hasil penelitian yang dilakukan oleh Martien Herna Susanti dan AT Sugeng Priyanto (2006: 24) menyimpulkan bahwa para mahasiswa yang terlibat aktif dalam aksi demonstrasi memiliki ciri-ciri antara lain; 1) aktif dalam organisasi kemahasiswaan atau kepemudaan; 2) mempunyai keberanian menyampaikan pendapat; 3) cukup mempunyai pengetahuan, sikap, nilai-nilai, pengalaman dan kepribadian untuk berpendapat; dan 4) mempunyai empati terhadap persoalan yang berkembang.

Jika dikaitkan dengan perkembangan demokrasi di Indonesia, maka dapat dikatakan bahwa demokrasi di Indonesia saat ini berjalan dengan baik. Demokrasi di Indonesia akan senantiasa berkembang mengikuti perkembangan pelakunya. Pelaku demokrasi yang dimaksud disini bukan hanya para politisi saja, melainkan semua unsur yang ada di dalam negara, termasuk mahasiswa. Mahasiswa sebagai agent of change memiliki peran tersendiri dalam dunia perpolitikan dan demokrasi di Indonesia. Mengutip pendapat Patta (2009) bahwa dalam politik modern terdapat empat hal yang harus diperhatikan. Pertama, adanya partsipasi politik dari beragai kalangan secara luas. Kedua, ada kompetisi politik yang sehat. Ketiga, adanya perpindahan kekuasaan dan adanya transpransi dalam pemilihan umum. Keempat, adanya kontrol dan pengawasan terhadap lembaga eksekutif, legislatif dan yudikatif. Apa yang dilakukan mahasiswa adalah bentuk kontrol mereka terhadap lembaga negara.

\section{KESIMPULAN}

1. Indonesia adalah negara dengan sistem demokrasi terbesar di Asean yang menjadi kiblat bagi beberapa negara di kawasan Asia. Terdapat beberapa indikator Indonesia dijadikan kiblat negara demokrasi, salah satunya adalah keberhasilan menyelenggarakan pemilihan umum yang terakhir dilaksanakan tahun 2019. Walaupun negara dengan sistem demokrasi terbesar, namun yang menjadi catatan adalah masih banyaknya praktik demokrasi yang bertentangan dengan konstitusi, salah satunya adalah tidak melibatkan rakyat dalam berbagai pengambilan kebijakan negara, padahal rakyat adalah pemegang kekuasaan teringgi.

2. Terjadi pergeseran nuansa demonstrasi di Indonesia. Saat ini banyak mahasiswa peserta aksi demonstrasi membawa poster yang kadang tidak ada kaitannya dengan substansi demonstrasi. Salah satu tujuan mereka adalah menunjukkan eksistensi mereka melalui peristiwa penting, salah 
satunya adalah melalui demonstrasi lalu di unggah di media sosial. Tujuannya adalah agar mendapat pujian dan diperhatikan orang lain. Apa yang mereka lakukan merupakan hal yang wajar seiring dengan perkembangan teknologi. Namun, yang perlu diperhatikan adalah jangan sampai sikap narsis mereka mengganggu kenyamanan orang lain.

3. Penjelasan diatas menjadi bukti bahwa perkembangan demokrasi di Indonesia saat ini berkembang dengan baik. Hal ini dibuktikan dengan besarnya perhatian mahasiswa terhadap keberlangsungan negara Indonesia. Hal-hal seperti ini perlu mendapat perhatian karena mahasiswa adalah agent of change dan agent of control.

\section{DAFTAR PUSTAKA}

Durand, V. M. dan Barlow, D. H. 2007. Psikologi Abnormal. Jilid I. Alih Bahasa : Linggawati Haryanto. Yogyakarta : Pustaka Pelajar.

Engkus, dkk. (2017). Perilaku Narsis Pada Media Sosial Di Kalangan Remaja Dan Upaya Penanggulangannya. Jurnal Penelitian Komunikasi 20 (2)

Ftithriana, Arin. (2016). Perbandingan Kualitas Demokrasi dalam Perspektif Kesetaraan Gender antara Indonesia dan Thailand. Jurnal Sawala 4 (2)

Halgin, R \& Whitbourne, S. (2010). Psikologi Abnormal. Jakarta: Salemba Humanika.

Hasse, J. (2012). Anarkisme Demonstrasi Mahasiswa: Studi Kasus Pada Universitas Islam Negeri Alauddin Makassar. Jurnal Studi Pemerintahan 3 (1)

Irawan, Beny Bambang. (2007). Perkembangan Demokrasi di Negara Indonesia. Jurnal Hukum dan Dinamika Masyarakat, 5 (1)

Izzati, Fadhila dan Ade Irma. (2018). Perilaku Narcissistic Pada Pengguna Instagram Di Kalangan Mahasiswa Universitas Serambi Mekkah. Jurnal IImiah Mahasiswa FISIP Unsyiah, 3 (2)

Moleong, Lexy J. (2018). Metode Penelitian Kualitatif, cetakan ke-37. Bandung : PT. Remaja Rosdakarya

Nihaya. (2011.) Demokrasi dan Problematikanya di Indonesia. Jurnal Sulesana, 6(2)

Othniel, Nugroho., dan Indri. 2007. Terlalu Lama Berdandan Mungkin Anda Narsis. Majalah Psikologi Plus. 1(9)

Patta, Abd. Kadir. (2009). Masalah dan Prospek Demokrasi. Jurnal Academica Untad, 1 (1)

Philip, O. (2007). Jangan Terlalu Dekat Narsisus. Majalah Psikologi Plus. 1 (09), 26-28

Raskin, Robert dan Howard Terry. (1988). A Principle Components Analysis of the Narcissistic Personality Inventory and Further Evidence of Its Construct Validity. Journal of Personality and Social Psychology. 54(5)

Sorokowska, A., Oleszkiewicz, A., Frackowiak, T., Pisanski, K., Chmiel, A., Sorokowski., P (2016). Selfies and personality: Who posts self-portrait photographs?. Personality and Individual Differences. 90 (3)

Susanti, Martien Herna dan AT. Sugeng Priyanto. 2006. Aksi Demonstrasi Mahasiswa dan Kebebasan Mengeluarkan Pendapat (Latar Belakang dan Faktor-Faktor Penyebabnya). Semarang: Fakultas Ilmu Sosial Universitas Negeri Semarang. 